\title{
An In-Depth Investigation of Roadside Crashes on Thai National Highways
}

\author{
Opas Somchainuck, Pichai Taneerananon, and Saravut Jaritngam* \\ Department of Civil Engineering, Prince of Songkla University, Hatyai, Songkhla 90110, Thailand \\ *E-mail: jaritngam@gmail.com (Corresponding author)
}

\begin{abstract}
Road crashes in Thailand cause some 13,000 deaths each year. About 12\% of these occur on national highways under the jurisdiction of the Department of Highways (DOH). For the past four years, 2007-2010, roadside crashes have constituted between $42.2-47.9 \%$, averaged $44 \%$ of the total crashes on the DOH's highways. This paper presents the result of in-depth roadside crash investigations with the aim of improving the roadside safety situation in Thailand. It was found that speeding was the main human error that contributed to the crashes, accounting for $57 \%$ of the causes. The cases involving vehicle hitting trees, the most common roadside hazard in Thailand, were found to be the most serious and common roadside crashes accounting for $72 \%$ with resulting 48 fatalities. The paper gives details of the investigation into the cause and consequences of these crashes. The authors urge DOH to take needed actions on the proposed strategies to deal with this immensely serious problem. The strategies are based on the DOH Roadside Safety Strategic Plan 2009-2013.
\end{abstract}

Keywords: Roadside crashes, roadside hazards, roadside safety strategies.

ENGINEERING JOURNAL Volume 17 Issue 2

Received 14 August 2012

Accepted 29 October 2012

Published 1 April 2013

Online at http://www.engj.org/

DOI:10.4186/ej.2013.17.2.63 


\section{Introduction}

\subsection{Background}

Road safety is a global concern, particularly in low and middle income countries and among vulnerable road users. By 2030, road deaths as a proportion of all deaths will become the world's fifth cause of death rising from its present $9^{\text {th }}$ position [1]. In such a scenario, Thailand is facing a challenging situation due to her having one of the highest road fatality rates in the world. Records for 2009 showed that, for one hundred thousand population, Thailand's road crash fatality rate stood at 17.0 (10,717 deaths), which was more than double the rate of Australia (6.9 or 1,507 deaths), while the number of injuries was close to one million [2]. The RISER project indicates that about $10 \%$ of all crashes are single vehicle accidents (SVA) that occur when the vehicles run off the road. When only fatal crashes are counted, ROR accidents account for a significant $45 \%$ of the tally. Crash investigations in the RISER project pointed to the fact that all fatal accidents involved impact speeds of $70 \mathrm{~km} / \mathrm{h}$ or higher; roadside structures such as signs, concrete walls, fences, and so on, were struck in $11 \%$ of all fatal SVA. Safety barriers are the object most impacted in ROR crashes. Although few injuries sustained in safety barrier crashes are found to be severe, the safety barriers themselves can pose a major hazard if not properly designed and installed [3] In Great Britain over the past 15 years, while occurrences of other crash types have been declining, crashes involving collision with roadside objects have remained fairly constant, and accounted for around 20,000 injuries yearly, a high $24 \%$ of which proved to be serious or fatal. Trees, crash barriers, and lamp-posts are three most frequently struck objects; with trees being the most hazardous: $33 \%$ of all tree crashes culminate in serious or fatal injuries. The collided object can be "unknown" as in cases involving a large group of some 7,000 collisions. [4]. In Thailand, despite the best of efforts by the Thai Government to reduce traffic accidents, the number of crashes still exceeds 13,000 resulting in more than one million injuries and several hundred thousand cases of disabilities every year [5].

One of the most overlooked causes of accidents has to do with roadside objects. Given its structure and placement, a fixed object by the side of the road, upon its being struck by a vehicle running off the carriageway, can cause, or is likely to cause, damage to vehicle, and/or injury or fatality to the occupant. Therefore, in order to reduce the severity of ROR accidents, more attention should be focused on hazardous roadside objects such as trees, utility poles, lamp-posts, sign posts, bridge rails and end treatments, fences, embankments and cuttings, ditches, guard rails (and guard rail end treatments), mail boxes and drainage structures [6]. This assumption is supported by findings in France, where the removal of trees closer than $2 \mathrm{~m}$ from the traffic lane edge had contributed to significant reductions in crashes: the average number of accidents was halved, and the number of fatal collisions reduced by a factor of four. Current guidelines for most European countries recommend that a clear zone be established for $80 \mathrm{~km} / \mathrm{h}$ roads, which is at least $4.5 \mathrm{~m}$ from the lane edge. No obstacles should be in this clear zone; if any exists, it should be properly removed or shielded [7]. The Michigan Tree Study reported that some $11 \%$ of tree crashes ended in fatalities. Such crashes often occurred on curved rural roads with narrow lane widths and high average daily traffic [8]. Tree crashes were also responsible for $25 \%$ of side-impact crashes with roadside hazards and produced $48 \%$ of side-impact-related fatalities [9]. Presented an interesting analysis of the relationship between the distance from trees to the travel lane and associated crash rates. [10]. Studies of highway bus crashes by the authors showed that more than $50 \%$ of these incidents were single bus accidents wherein the errant buses ran off the road and collided with roadside objects [11]. 


\subsection{Purpose and Objectives}

The purpose of this paper is to provide the concerned authorities with awareness and to take urgent actions in order to reduce the number of roadside crashes in Thailand. Three specific objectives of this paper are as follows:

- To understand the situation of roadside crashes on national highways in Thailand by using statistical information;

- To determine the contribution factors of roadside crashes by conducting in-depth crash investigations; and

- To highlight roadside safety strategies to the DOH for further actions.

\section{Roadside Crash Situation in Thailand}

Figure 1 shows the trends of total crashes and roadside crashes on the national highways from 1999 to 2010. On average, roadside crashes constitute $41.7 \%$ of total crashes on DOH highways over the past twelve years resulting in some 500 annual fatalities. However, for roadside crashes, the trend initially increases from the years 1999 to 2004. After that it decreases to a minimum of 5,425 cases in 2006 and become relative steady from 2007 to 2010, signifying the fact that it remains a big challenge to be addressed by $\mathrm{DOH}$.

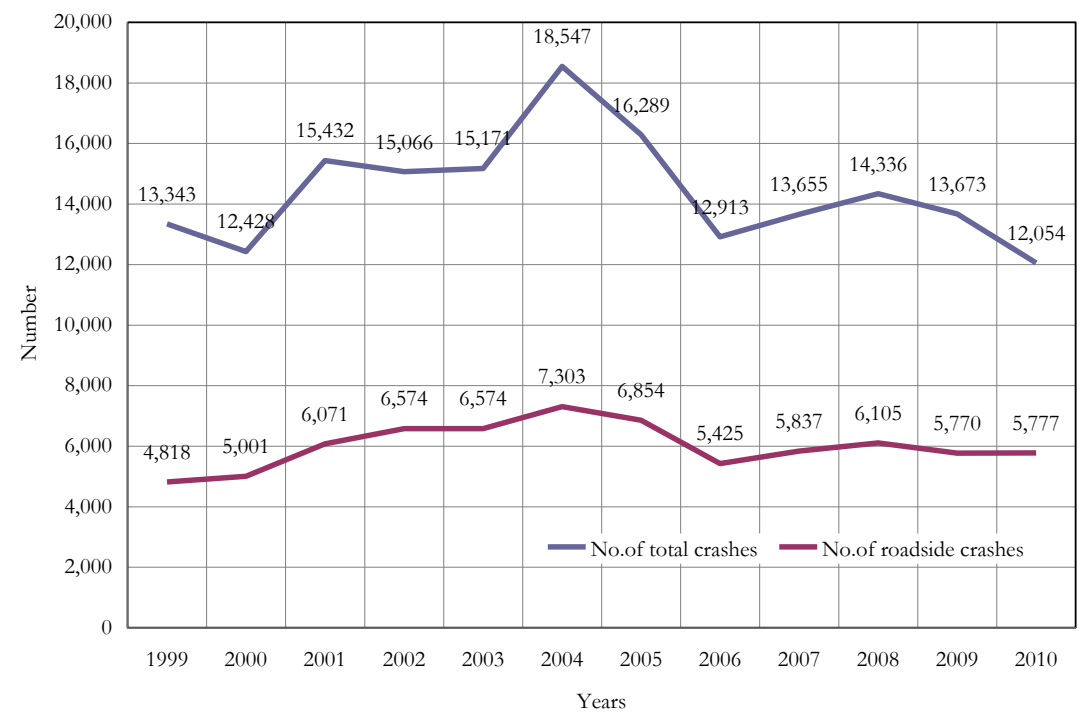

Fig. 1. Trends of total and roadside crashes on DOH national highways from 1999 - 2010 [12].

Table 1 shows the situation from roadside crashes on national highways for the past four years, 20072010. The roadside crashes constitute between 42.2 - $47.9 \%$ of the total crashes on the DOH's highways or average of $44 \%$ over the 4 -year period.

Table 1. Situation of roadside crashes on national highways.

\begin{tabular}{lccr}
\hline Year & Total crashes & Roadside crashes & Percent \\
\hline 2007 & 13,655 & 5,837 & 42.75 \\
2008 & 14,336 & 6,105 & 42.59 \\
2009 & 13,673 & 5,770 & 42.20 \\
2010 & 12,054 & 5,777 & 47.90 \\
Average & 13,430 & 5,872 & 44.00 \\
\hline
\end{tabular}

Source: Bureau of Highway Safety, Department of Highways 2008-2011.

There have been earlier studies of roadside crashes using the annual data from crashes on national highways as reported by the DOH. However, these studies do not get into details of the cause of the crashes [13]. 


\section{Principles of In-Depth Crash Analysis}

\subsection{General Concept}

An in-depth crash analysis consists of two main procedures: investigation and reconstruction. An accident investigation is performed to determine the causes of as well as possible means of preventing an accident. The process would normally start with inspection of an accident site and gathering of evidence. The scenario would then be "played back" to enable investigators to figure out the cause of the crash. Such findings can lead to effective measures for preventing or minimizing injuries. A crash reconstruction is the process that all information, collected from the investigation step and other sources, are simulated to explain the chain of events, identify major causes, and to propose corrective/preventative measures [14].

\subsection{Crash Investigation}

The crash investigator must have fundamental knowledge of accidents, the road and its environment, and vehicles of all types, especially the dynamics of vehicular movement. The next subsections summarize the necessary data for the process [15].

\subsubsection{Crash Scene Information}

At the crash site, the investigator must choose a reference point $(\mathrm{RP})$ as the origin for all measurements. From the RP, he proceeds to measure out the point of impact (POI), where the vehicles collided or where roadside obstacles were hit, and the point of rest (POR), where the vehicle stopped. Traces of debris or broken parts from the vehicles may be used to establish POI and POR which in turn would help to delineate the paths of the vehicles involved. In addition, skid marks and yaw marks can be used to explain the directions of movement, evasive action, or unlawful behaviour.

Sketches may be made to illustrate the crash configuration. Better still, photograph and video records should be taken to clearly explain the crash scene. General information, including date and time of a crash, weather, road surface condition, or previous accidents occurring at the current location, should also be recorded

\subsubsection{Road User Information}

Interviews of the driver and occupants should be performed to answer the question of what happened during the crash. Where possible, the injured person is also interviewed; as well as eye witnesses and those familiar with the location.

During the interview, allow the interviewees to describe their perception of events; avoid leading questions or implying. Moreover, identity and ownership documents (e.g. driver's license, ID card, and passport etc.) of driver and occupants must be checked.

\subsubsection{Vehicular Information}

Conditions of the crash vehicles are to be carefully examined. These include details of vehicle exterior (e.g. metal fold, wheel and tire, windshield, and wipers, etc.) and interior (e.g. instrument panel, steering columns, rear-view mirrors, seat cushion, and seatback, etc.) together with the age and condition of the vehicle part. Functioning of parts such as lights, brakes, and other safety restraining system should be tested out. The damages of different parts are to be noted. In addition, pictures of damages should be taken from different angles.

\subsubsection{Road and Environment Information}

General characteristics of the roadway at the crash site are to be observed; such as width, surface type, existing signs, markings, sidewalk, pedestrian crossing, speed limits, visibility, obstacles (e.g. utility poles, trees, and rocks), road name, and direction of travel. Layout of buildings can also be included, especially if 
the resting position of the vehicles is at or near buildings. Also look for signs of damage on the road surface or shoulder, large potholes, and on-going construction. Take note of features that might have caused loss of control; such as abrupt change in the surface of the carriageway/shoulder, poor lighting, water pooling on the surface, etc.

\subsection{Crash Reconstruction}

A crash reconstruction is the compilation of all items of evidence collected from the investigation process for a "playback" to illustrate the "how" and "why" of a crash. Knowledge of mathematics and Newtonian physics must be applied in order to establish the chain of events starting from Before (pre-crash), During (crash), and After (post-crash) stages. The process is essential for the examination and understanding of factors contributing to or causes behind the crash [16].

\subsection{Benefits of In-Depth Crash Analysis}

According to the Swedish Road Administration, a range of benefits can be gained from in-depth crash studies, as listed below:

- Lead to positive changes to the road and its environment.

- Provide data for long-term work in road design and vehicle development; and information for use by the police in traffic surveillance and other road safety efforts.

- Used in the study on effects of alcohol and drugs on driving.

- Help to heighten awareness of the role of seatbelts and other on-vehicle safety devices.

- Used as data for collaborations among authorities, agencies and companies to influence road safety.

Moreover, multi-disciplinary experts, such as vehicle mechanics, road designers, traffic engineers and behavioral scientists, should work together to analyze the result of chain-of-events reconstruction in order to gain better insight into the causes of, as well as means of preventing crashes. Experts in supporting areas, such as medical services, police, emergency services and local authorities, can also benefit from the insights gained from crash analyses [17].

\section{Roadside Crash Investigation: Case Studies}

In Thailand, crash data are not readily available and they are often kept in paper format. To do any analysis, researchers need to go back to the paper records and start to compile these data. In order to get the big picture view of the roadside crash situation as presented in Table 1, the first author who is DOH engineer working in the south of Thailand needed to access the crash records from DOH offices in this region. However, those records do not contain detailed crash information, therefore, to obtain this information, the authors have been conducting road crash investigations since 2008 with the support of the Office of Transport and Traffic Policy and Planning [18] and the Department of Land Transport [19] the crashes investigated include roadside crashes. The crashes reported in this paper were extracted from these reports plus the recent 16 cases which have been investigated by the authors. The investigated roadside crashes involve passenger vehicles, including cars, vans, pickups, and buses. The highway sections where these crashes occurred are: highway no.4, highway no.41, highway no.42, highway no.43, highway no.401, highway no.414, highway no.4028 and highway no. 4029 (see Fig. 2). A total of 21 crashes were investigated for highway sections in Chumphon, Surattani, Songkhla, Phuket and Narathiwat provinces as shown in Fig. 2. 

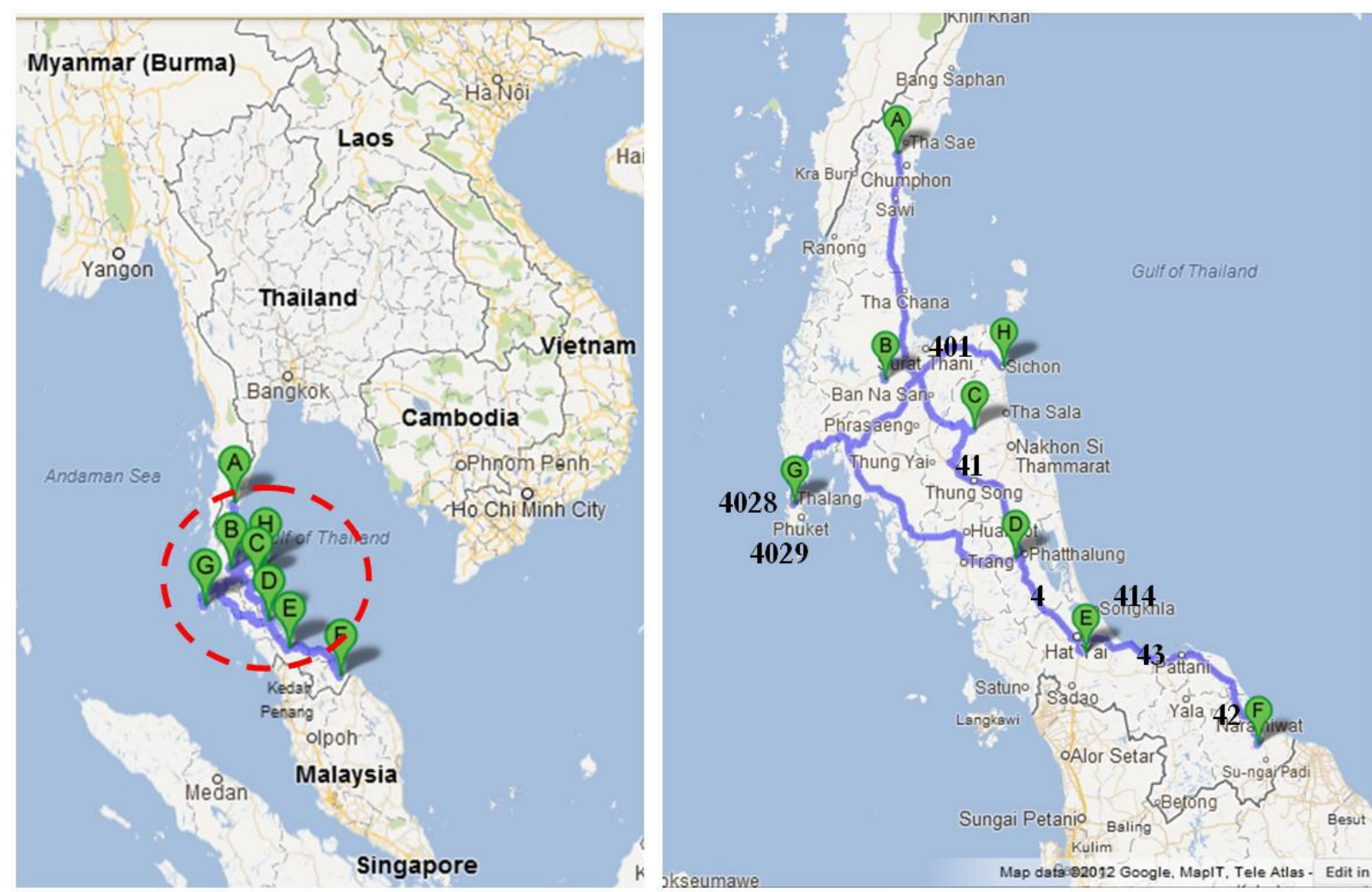

Fig. 2. Location of the roadside crashes on 8 national highway sections.

Summary of findings of the investigated roadside crashes are given in Tables 2 and 3. It is seen that out of the total 21 cases, 18 involve fatalities, while 3 involve serious injuries. The consequences of these crashes result in 63 fatalities, 85 serious injuries, and 142 slight injuries. The causes of these crashes are presented in Table 3. They are categorized into three main contributing factors, i.e. human errors, vehicle defects, and road and environment defects.

In general roadside crashes constitute a high proportion of all crashes on DOH highways, amount to more than 40\%, as shown in Fig.1 and Table 1. However, for some highway sections, they can form a majority of all crashes on these highway sections. For example, on Highway no. 414, they make up $92 \%$ of the total crashes in 2011, and 100\% in 2012 (up to September); for Highway no. 4, the percentage of road side crashes are 56 for 2011, and 100\% in 2012 (up to September); and for Highway no.43, roadside crashes make up $83 \%$ of the total crashes in 2011.

\subsection{Detailed Crash Analysis}

Table 4 presents detailed analysis of roadside crashes and casualties. A total of 21 cases were investigated over the four-year period of crash investigation and reconstruction research. These cases include 63 fatalities, 85 serious injuries and 142 slight injuries. They cover the area of five main provinces in southern Thailand namely, Chumphon, Phuket, Songkhla, Surattani, and Narathiwas province. A total of 291 people and 21 vehicles were involved in the crashes. Of the total 21 vehicles, there are 6 passenger cars $(29 \%), 6$ buses $(29 \%) 6$ vans $(29 \%)$ and 3 pickups (13\%). In addition, it was found that the 6 van crashes caused the largest number of casualties and with the highest severities. In these crashes, 19 passengers were killed while 35 passengers and 13 passengers were seriously and slightly injured respectively. Moreover, a leading percentage of roadside crashes were caused by speeding, 13 out 21 crashes or $61.9 \%$ as show in the Table. As regards the type of roadside hazards hit by errant vehicles, it was found that tree is the most common, making up $62 \%$ of the hazards. 
Table 2. Summary of 21 roadside crash investigations on 8 southern highway sections.

\begin{tabular}{|c|c|c|c|c|c|c|}
\hline \multirow[b]{2}{*}{ No } & \multirow[b]{2}{*}{$\begin{array}{c}\text { Date/ Time of } \\
\text { Crash }\end{array}$} & \multirow[b]{2}{*}{ Location } & \multirow[b]{2}{*}{ Vehicles } & \multicolumn{3}{|c|}{ Number of Victims } \\
\hline & & & & Fatalities & $\begin{array}{l}\text { Serious } \\
\text { Injuries }\end{array}$ & $\begin{array}{c}\text { Slight } \\
\text { Injuries }\end{array}$ \\
\hline 1 & $\begin{array}{l}26 \text { August } 2008 \\
1130 \text { hr. }\end{array}$ & $\begin{array}{l}\text { Highways no. } 42 \\
\text { Yi-ngo, Narathiwat }\end{array}$ & Van & 5 & 5 & - \\
\hline 2 & $\begin{array}{l}31 \text { August } 2008 \\
0820 \text { hr. }\end{array}$ & $\begin{array}{l}\text { Highways no.4 } \\
\text { Bangklam, Songkhla }\end{array}$ & Van & 1 & 5 & 5 \\
\hline 3 & $\begin{array}{l}28 \text { September } 2008 \\
0450 \text { hr. }\end{array}$ & $\begin{array}{l}\text { Highways no. } 414 \\
\text { Hatyai, Songkhla }\end{array}$ & Car & 1 & - & - \\
\hline 4 & $\begin{array}{l}8 \text { October } 2008 \\
2210 \text { hr. }\end{array}$ & $\begin{array}{l}\text { Highways no.414 } \\
\text { Hatyai, Songkhla }\end{array}$ & Car & 1 & 2 & - \\
\hline 5 & $\begin{array}{l}11 \text { January } 2009 \\
1630 \text { hr. }\end{array}$ & $\begin{array}{l}\text { Highways no. } 42 \\
\text { Yi-ngo,Narathiwat }\end{array}$ & Pickup & 10 & 4 & 7 \\
\hline 6 & $\begin{array}{l}2 \text { April } 2010 \\
1500 \mathrm{hr} .\end{array}$ & $\begin{array}{l}\text { Highways no.43 } \\
\text { Hatyai, Songkhla }\end{array}$ & Pickup & 5 & 4 & - \\
\hline 7 & $\begin{array}{l}29 \text { February } 2011 \\
1030 \text { hr. }\end{array}$ & $\begin{array}{l}\text { Highways no. } 414 \\
\text { Hatyai, Songkhla }\end{array}$ & Car & 3 & 3 & - \\
\hline 8 & $\begin{array}{l}8 \text { March } 2011 \\
0840 \text { hr. }\end{array}$ & $\begin{array}{l}\text { Highways no. } 4029 \\
\text { Kathu, Phuket }\end{array}$ & Bus & 1 & 7 & 39 \\
\hline 9 & $\begin{array}{l}21 \text { March } 2011 \\
1330 \text { hr. }\end{array}$ & $\begin{array}{l}\text { Highways no.4 } \\
\text { Bangklam, Songkhla }\end{array}$ & Bus & - & 2 & 20 \\
\hline 10 & $\begin{array}{l}15 \text { July } 2011 \\
1845 \mathrm{hr} .\end{array}$ & $\begin{array}{l}\text { Highways no.4 } \\
\text { Ruttaphum, Songkhla }\end{array}$ & Bus & 1 & 7 & 12 \\
\hline 11 & $\begin{array}{l}17 \text { September } 2011 \\
0130 \text { hr. }\end{array}$ & $\begin{array}{l}\text { Highways no. } 414 \\
\text { Hatyai, Songkhla }\end{array}$ & Car & 1 & - & - \\
\hline 12 & $\begin{array}{l}25 \text { September } 2011 \\
1600 \mathrm{hr} .\end{array}$ & $\begin{array}{l}\text { Highways no.4 } \\
\text { Ruttaphum, Songkhla }\end{array}$ & Car & 1 & 1 & - \\
\hline 13 & $\begin{array}{l}22 \text { October } 2011 \\
0800 \mathrm{hr} .\end{array}$ & $\begin{array}{l}\text { Highways no. } 4028 \\
\text { Chalong, Phuket }\end{array}$ & Bus & 1 & 9 & 19 \\
\hline 14 & $\begin{array}{l}26 \text { October } 2011 \\
1000 \mathrm{hr} .\end{array}$ & $\begin{array}{l}\text { Highways no. } 4029 \\
\text { Kathu, Phuket }\end{array}$ & Bus & - & 4 & 18 \\
\hline 15 & $\begin{array}{l}4 \text { November } 2011 \\
1150 \mathrm{hr} .\end{array}$ & $\begin{array}{l}\text { Highways no. } 43 \\
\text { Na- Mom, Songkhla }\end{array}$ & Van & 1 & 2 & 1 \\
\hline 16 & $\begin{array}{l}6 \text { November } 2011 \\
1550 \mathrm{hr} .\end{array}$ & $\begin{array}{l}\text { Highways no. } 43 \\
\text { Hatyai, Songkhla }\end{array}$ & Pickup & 3 & 2 & 2 \\
\hline 17 & $\begin{array}{l}23 \text { January } 2012 \\
0900 \mathrm{hr} .\end{array}$ & $\begin{array}{l}\text { Highways no.4 } \\
\text { Lamae, Chumphon }\end{array}$ & Van & - & 5 & 7 \\
\hline 18 & $\begin{array}{l}22 \text { February } 2012 \\
0320 \text { hr. }\end{array}$ & $\begin{array}{l}\text { Highways no. } 414 \\
\text { Hatyai, Songkhla }\end{array}$ & Personal Car & 6 & - & - \\
\hline 19 & $\begin{array}{l}\text { 29 June } 2012 \\
0640 \mathrm{hr} .\end{array}$ & $\begin{array}{l}\text { Highways no. } 42 \\
\text { Yi-ngo, Narathiwat }\end{array}$ & Van & 4 & 11 & - \\
\hline 20 & $\begin{array}{l}\text { 1July } 2012 \\
0515 \text { hr. }\end{array}$ & $\begin{array}{l}\text { Highways no.4 } \\
\text { Lang-Suan,Chumphon }\end{array}$ & Van & 8 & 7 & - \\
\hline 21 & $\begin{array}{l}3 \text { June } 2012 \\
0520 \text { hr. }\end{array}$ & $\begin{array}{l}\text { Highways no.401 } \\
\text { Kanchanadit,Surattani }\end{array}$ & Bus & 10 & 5 & 12 \\
\hline & & & & 63 & 85 & 142 \\
\hline
\end{tabular}

Source: Crash investigations by authors. 
Table 3. Cause of crashes.

\begin{tabular}{|c|c|c|c|c|c|c|c|}
\hline \multirow[b]{2}{*}{ No. } & \multirow[b]{2}{*}{ Date of crash } & \multirow[b]{2}{*}{ Location } & \multicolumn{4}{|c|}{ Causes } & \multirow{2}{*}{$\begin{array}{r}\text { Age } \\
\text { of } \\
\text { driver }\end{array}$} \\
\hline & & & $\begin{array}{c}\text { Human } \\
\text { errors }\end{array}$ & $\begin{array}{l}\text { Vehicle } \\
\text { defects }\end{array}$ & $\begin{array}{c}\text { Road\& } \\
\text { environment } \\
\text { defects }\end{array}$ & $\begin{array}{l}\text { Roadside } \\
\text { hazards }\end{array}$ & \\
\hline 1 & 26 Aug 2008 & Highways no.42 & Speeding & - & - & Tree & 41 \\
\hline 2 & 31 Aug 2008 & Highways no.4 & Drowsy & - & - & Tree & 33 \\
\hline 3 & 28 Sept 2008 & Highways no.414 & Drowsy & - & - & Tree & 41 \\
\hline 4 & 8 Oct 2008 & Highways no.414 & Speeding & $\begin{array}{l}\text { Blown } \\
\text { tire }\end{array}$ & - & $\begin{array}{c}\text { Guardrail/ } \\
\text { Tree }\end{array}$ & 25 \\
\hline 5 & 11 Jan 2009 & Highways no.42 & Speeding & - & - & Tree & 33 \\
\hline 6 & 2 Apr 2010 & Highways no.43 & - & - & $\begin{array}{l}\text { Slippery } \\
\text { surface }\end{array}$ & Tree & 50 \\
\hline 7 & 29 Feb 2011 & Highways no.414 & Speeding & - & - & Tree & 21 \\
\hline 8 & 8 Mar 2011 & Highways no.4029 & - & $\begin{array}{l}\text { Brake } \\
\text { failure }\end{array}$ & - & Guardrail & na \\
\hline 9 & 21 Mar 2011 & Highways no.4 & Drowsy & - & - & Tree & 27 \\
\hline 10 & 15 Jul 2011 & Highways no.4 & $\begin{array}{l}\text { Unsafe } \\
\text { driving } \\
\text { maneuver }\end{array}$ & - & $\begin{array}{l}\text { Slippery } \\
\text { surface }\end{array}$ & $\begin{array}{c}\text { Electric } \\
\text { Pole/Curb } \\
\text { /Tree/ } \\
\text { Side slope }\end{array}$ & 52 \\
\hline 11 & 17 Sept 2011 & Highways no.414 & Speeding & - & - & Tree & 31 \\
\hline 12 & 25 Sept 2011 & Highways no.4 & Drowsy & - & - & Tree & 26 \\
\hline 13 & 22 Oct 2011 & Highways no.4028 & - & $\begin{array}{l}\text { Brake } \\
\text { failure }\end{array}$ & - & $\begin{array}{c}\text { Guardrail } \\
\text { /Tree }\end{array}$ & 34 \\
\hline 14 & 26 Oct 2011 & Highways no.4029 & - & $\begin{array}{l}\text { Brake } \\
\text { failure }\end{array}$ & - & Guardrail & na \\
\hline 15 & 4 Nov 2011 & Highways no.42 & Drowsy & - & - & Tree & 33 \\
\hline 16 & 6 Nov 2011 & Highways no.43 & Speeding & - & $\begin{array}{l}\text { Slippery } \\
\text { surface }\end{array}$ & Tree & 22 \\
\hline 17 & 23 Jan 2012 & Highways no.4 & Drowsy & - & - & Tree & 24 \\
\hline 18 & 22 Feb 2012 & Highways no.414 & Speeding & - & - & Tree & 26 \\
\hline 19 & 29 Jun 2012 & Highways no.42 & Drowsy & - & - & Tree & 25 \\
\hline 20 & 1 Jul 2012 & Highways no.4 & Drowsy & - & - & Tree & 19 \\
\hline 21 & 3 Jun 2012 & Highways no.401 & Speeding & - & - & $\begin{array}{c}\text { Electric } \\
\text { pole/Curb }\end{array}$ & 58 \\
\hline
\end{tabular}


Table 4. Detailed analysis of 21 roadside crashes and casualties.

\begin{tabular}{|c|c|c|c|c|c|}
\hline Item & Number & Percentage & Item & Number & Percentage \\
\hline Type of involved vehicle & & & Hourly distribution & & \\
\hline Passenger car & 6 & 29 & $24.01-06.00$ & 5 & 24 \\
\hline Van & 6 & 29 & 06.01-12.00 & 8 & 38 \\
\hline Bus & 6 & 29 & $12.01-18.00$ & 6 & 29 \\
\hline Pick up & 3 & 13 & $18.01-24.00$ & 2 & 10 \\
\hline Causes & & & Weekly distribution & & \\
\hline Speeding & 13 & 62 & Sunday & 3 & 14 \\
\hline Sleepy/Fatigue & 5 & 22 & Monday & 2 & 10 \\
\hline Vehicle defects & 3 & 13 & Tuesday & 6 & 29 \\
\hline \multirow[t]{4}{*}{ Inclement weather } & 2 & 9 & Wednesday & 2 & 10 \\
\hline & & & Thursday & 2 & 10 \\
\hline & & & Friday & 2 & 10 \\
\hline & & & Saturday & 4 & 19 \\
\hline Roadside objects hit & & & Monthly Distribution & & \\
\hline Tree & 18 & 62 & $1-3$ & 6 & 29 \\
\hline Guardrail & 4 & 15 & $4-6$ & 3 & 14 \\
\hline Electric pole & 3 & 10 & $7-9$ & 8 & 38 \\
\hline Curb & 2 & 7 & $10-12$ & 4 & 19 \\
\hline Traffic sign & 1 & 3 & & & \\
\hline $\begin{array}{l}\text { Guide post \& KM } \\
\text { post }\end{array}$ & 1 & 3 & & & \\
\hline Crash location & 15 & 71 & Weather condition & 14 & 67 \\
\hline Straight sections & 6 & 29 & Clear & 3 & 14 \\
\hline Curve sections & & & Rain & 4 & 19 \\
\hline & & & Cloudy & & \\
\hline
\end{tabular}

\subsection{Detailed Injury Analysis}

The severity of injury resulting from of roadside crashes is often high because the hit object is mostly fixed and robust, especially large trees and utility poles. Moreover, these hazardous objects are often located close to the roadway and well within the clear zone. Table 5 presents the number of casualties resulting from these crashes categorized by level of severity, together with the estimated crash cost and cause of the crashes. From the table, it can be estimated that on average one roadside crash results in 3 fatalities, 4 serious injuries and 6.8 slight injuries, and costing 18.1 million baht.

Table 5. Type of roadside hazards hit by errant vehicles.

\begin{tabular}{|c|c|c|c|c|c|c|}
\hline $\begin{array}{l}\text { Roadside } \\
\text { Hazard }\end{array}$ & $\begin{array}{c}\text { No. of } \\
\text { Roadside } \\
\text { Hazards }\end{array}$ & Fatalities & $\begin{array}{l}\text { Serious } \\
\text { Injuries }\end{array}$ & $\begin{array}{c}\text { Slight } \\
\text { Injuries }\end{array}$ & $\begin{array}{c}\text { Crash Cost } \\
\text { (million baht)* }\end{array}$ & $\begin{array}{l}\text { Cause of } \\
\text { Crashes }\end{array}$ \\
\hline Trees only & 15 & 48 & 51 & 42 & $290,795,000$ & $\begin{array}{c}\text { Speeding\& } \\
\text { Drowsy driving }\end{array}$ \\
\hline $\begin{array}{l}\text { Trees } \\
\& G u a r d r a i l\end{array}$ & 2 & 2 & 11 & 19 & $13,926,500$ & Brake failure \\
\hline Guardrail & 2 & 2 & 11 & 57 & $9,613,500$ & Brake failure \\
\hline $\begin{array}{l}\text { Tree/Electric } \\
\text { Pole/Curb \& } \\
\text { Side Slope }\end{array}$ & 2 & 11 & 12 & 12 & $65,464,000$ & $\begin{array}{l}\text { Speeding\& } \\
\text { inclement } \\
\text { weather }\end{array}$ \\
\hline Total & 21 & 63 & 85 & 142 & $399,799,000$ & (US \$ 12,251580) \\
\hline
\end{tabular}




\section{More Actions Needed To Improve Roadside Safety}

It is clear from the analysis of $\mathrm{DOH}$ data and the in-depth investigations that the roadside crash situation is very serious as it constitutes an average of $42 \%$ of all DOH crashes over the past 12 years, this average percentage rises to 44 , when considered only figures for the past 4 years. This is despite the fact that DOH has put in place the Department of Highways Roadside Safety Strategic Plan 2009-2013 since 2009. To improve roadside safety situation in Thailand, and hence reduce the number of unnecessary road deaths which are the results of avoidable roadside hazards, the authors propose that more actions by DOH are urgently needed; this is in line with the UN's call for A Decade of Action for Road Safety 2011-2020. Even though reducing roadside hazard is a key action needed to reduce roadside casualties, there are other preventive strategies that require further actions by DOH as outlined in the DOH Roadside Safety Strategic Plan which the second author has contributed to its development.

\subsection{Department of Highways Roadside Safety Strategic Plan 2009-2013}

To improve roadside safety situation on national highways, the DOH needs to implement further actions in its Roadside Safety Strategic Plan 2009-2013. So far it has taken actions on strategy number 4 by putting guard rails and getting rid of some trees. Fig. 3 shows guard rails installed at curve section and Figs. 4 and 5 show the elimination of existing trees in the median when a $3 \mathrm{~km}$. section of a highway in Songkhla was reconstructed. However, all strategies and actions in the plan need to be implemented. The plan consists of five strategies as follows:

Strategy 1: Increase the awareness for roadside safety;

Strategy 2: Increase knowledge on the cause, location, mechanism, costs and effective treatments of roadside crashes;

Strategy 3: Prevent vehicles from running off the highway;

Strategy 4: Protect errant vehicles from hitting roadside objects or rolling over;

Strategy 5: Reduce the severity of crash impact for the occupants of errant vehicles [20].
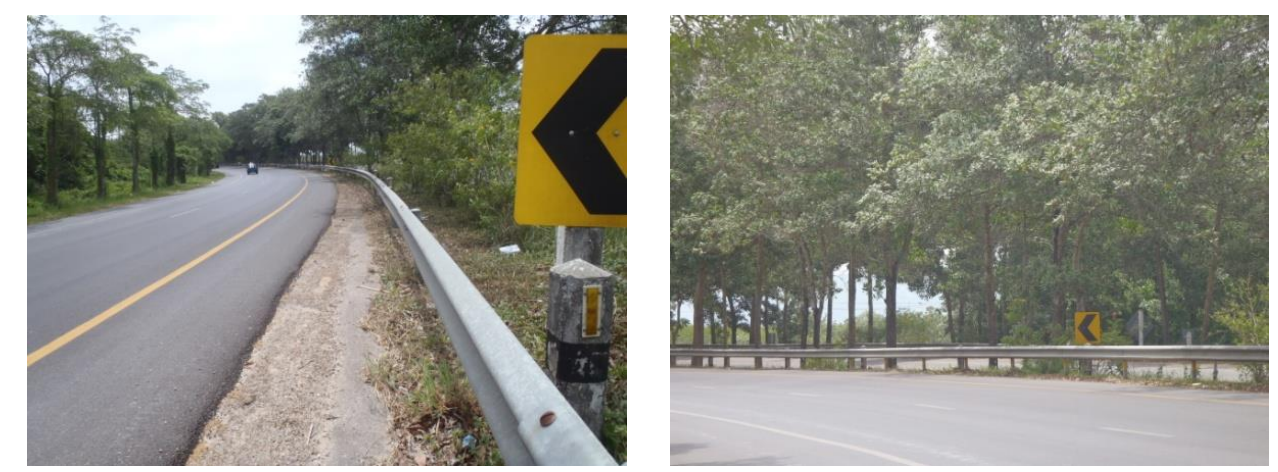

Fig. 3. Guard rails were installed to protect errant vehicles from impacting trees.
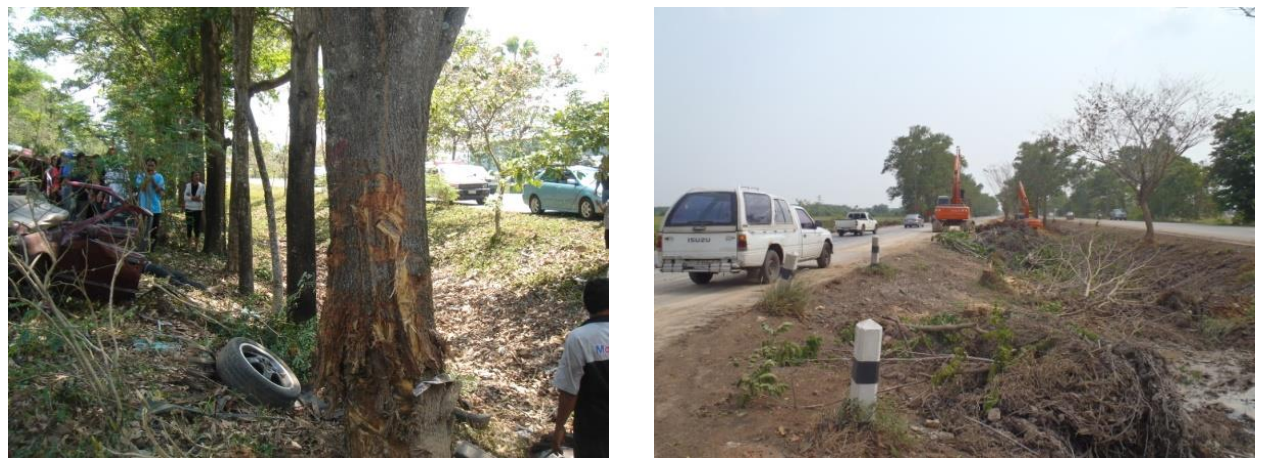

Fig. 4. Roadside crash in the median where trees were hit and safety improvement made during reconstruction and existing trees in the median removed. 

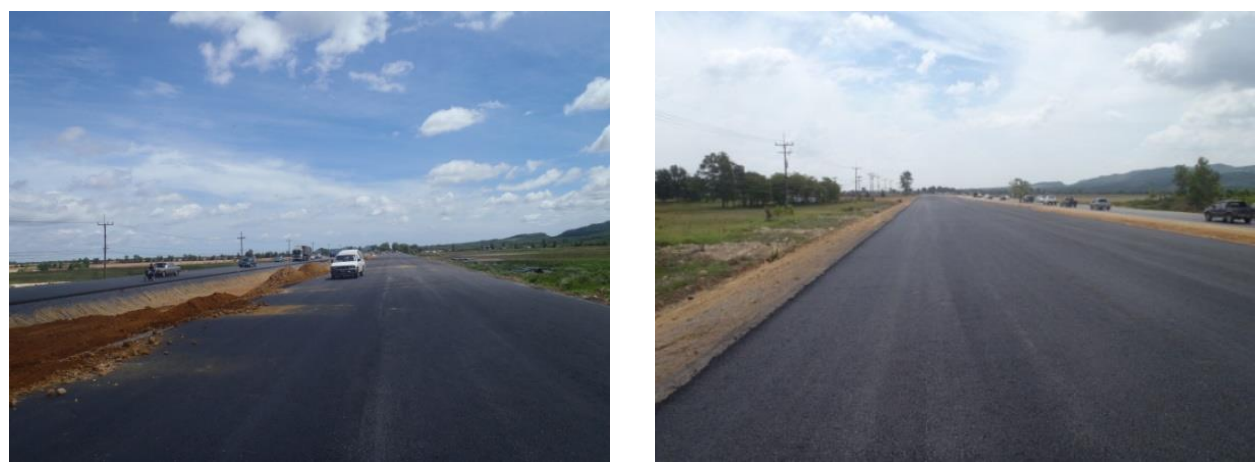

Fig. 5. Improvement in roadside safety after treatment of median by removal of trees.

\section{Conclusions}

This practical paper addresses the roadside safety challenge in Thailand. It is clear from the analysis of $\mathrm{DOH}$ data and the in-depth investigations that the roadside crash situation is very serious as it constitutes an average of $42 \%$ of all $\mathrm{DOH}$ crashes over the past 12 years, this average percentage rises to 44 , when considered only the figures for the past 4 years. The number of fatalities from these crashes amount to some 500 annually; these occur despite the fact that $\mathrm{DOH}$ has in place the Department of Highways Roadside Safety Strategic Plan 2009-2013 since 2009. The in-depth investigations of 21 roadside crashes show that the main human errors causing a crash is speeding accounting for about $62 \%$ of the crashes, followed by driving while drowsy $22 \%$. The investigations also show that roadside trees, planted well within the clear zone are the object most impacted by errant drivers, accounting for $72 \%$ of the total, and resulting in 48 deaths.

To improve roadside safety situation in Thailand, and hence reduce the number of unnecessary road deaths which are the results of avoidable roadside hazards; the authors has proposed that more actions by DOH are urgently needed; this is in line with the UN's call for A Decade of Action for Road Safety 20112020. Even though reducing roadside hazard is a key action needed to reduce roadside casualties, there are other strategies that require more actions as outlined in the DOH Roadside Safety Strategic Plan. The strategies for prevention of roadside crashes are no less important and need to be concurrently implemented. They include: increase the awareness for roadside safety; increase knowledge on the cause, location, mechanism, costs and effective treatments of roadside crashes; and prevent vehicles from running off the highway.

\section{References}

[1] World Health Organization. (2009). Global Status Report On Road Safety: Time For Action, Geneva. [Online]. Available: http://www.who.int/violence_injury_prevention/road_safety_status/2009

[2] UN. (Sept., 2011). Improving global road safety [Online]. Available: http://www.who.int/roadsafety/ about/resolutions/sept_2011_sg_report_en.pdf

[3] OECD. (2010). A record decade for road safety [Online]. Available: http://www.international transportforum.org/Press/PDFs/2010-09-15IRTAD.pdf

[4] S. Proctor, "Single vehicle loss of control collisions and passive safety, traffic signs, signals, and lighting," in the Passive Revolution Conference, Institution of Civil Engineers, London, 2005.

[5] P. Taneerananon, "Road safety: A human challenge," in Proceedings of the $3^{\text {rd }}$ National Transport Conference, invited paper, Khon Kaen, Thailand, TS3-9, 2006.

[6] C. N. Kloeden, A. J. McLean, M. R. J. Baldock, and A. J. T. Cockington, "Severe and fatal car crashes due to roadside hazards," the Motor Crash Commission, NHMRC Road Crash Research Unit, the University of Adelaide, Australia, Final Rep., 1999.

[7] CETE Évaluation sur les vitesses de la suppression des plantations d'alignement - cas de la RD1314 en Seine-Maritime. CETE Centre d'Études techniques de l'équipement Normandie Centre, Division exploitation sécurité gestion des infrastructures, $2000 \& 2002$.

[8] A. J. Ziegler, "Guide to management of roadside trees," Michigan Department of Transport, Technical Report FHWA- IP-86-17, 1986. 
[9] M. H. Ray, L. A. Troxel, and J. F. Carney, III, "Characteristics of side impact accidents involving fixed roadside objects," Journal of Transportation Engineering, vol. 117, no. 3, pp. 281-297, 1991.

[10] T. R. Neuman, R. Pfefer, K. L. Slack, K. K. Hardy, K. Lacy, and C. Zegeer, "Volume 3: A Guide for Addressing Collisions with Trees in Hazardous locations," Washington DC, USA, NCHRP Report $500,2003$.

[11] P. Taneerananon, and O. Somchainuek, "Bus crash situation in Thailand: Case study," Journal of the Eastern Asia Society for Transportation Studies, vol. 6, pp. 3617 - 3628, 2005.

[12] Bureau of Highway Safety "Traffic crashes on national highways 2010," Department of Highways, Ministry of Transport, Thailand, Annual Rep., 2011.

[13] P. Taneerananon, and W. Cheewapattananuwong, "Fatal and injury crashes resulting from roadside hazards," in Proceedings of the 21st ARRB and 11th REAAA Conference, Queensland, Australia, 2003.

[14] D. J. Van Kirk, Accident investigation and reconstruction. CRC Press LLC, USA, 2001.

[15] R. W. Rivers, Traffic Accident Investigation, 2nd ed. The Institute of Police Technology and Management, University of North Florida, USA, 2005.

[16] M. B. Islam and Y. Tanaboriboon, "Crash investigation and reconstruction the new experience in developing countries: Thailand case study," in Proceedings of the 13 th International Conference on Road Safety on four Continents, Warsaw, Poland, 2005, pp. 874-884.

[17] Swedish Road Administration "In-depth studies of fatal accidents save lives," Sweden, 2005.

[18] P. Taneerananon, S. Taneerananon, T. Ravirungsun, S. Thaina, L. Khooburat, P. Thongchim, and W. Wetchaphinan, "Application of accident investigation model (Southern Region)," Office of Transport and Traffic Policy and Planning, Final Rep., 2009.

[19] P. Taneerananon, S, Taneerananon, S. Thaina, L. Khooburat, and P. Thongchim, "In-depth crash investigation (Southern Region)," Department of Land Transport, Final Rep., 2012.

[20] V. Ruangsooksriwong, A. Luangboriboon, F. Laohasawad, P. Prapongsena, and P. Taneerananon, “Thailand Department of Highways' Roadside Safety Strategic Plan 2009-2013," Journal of Society for Transportation and Traffic Studies (JSTS), vol. 1, no. 3, pp. 68-75, 2010. 